\title{
Where lies the test?
}

\begin{abstract}
The Food and Drug Administration last week issued a set of regulations designed to help combat a growing scandal over drug testing in the United States. Colin Norman reports from Washington
\end{abstract}

A Relatively unremarkable scientific paper, published early in 1972, has touched off a major scandal over the testing and regulation of drugs in the United States. It has led to allegations that some drug companies have conducted sloppy animal tests, faked results and presented misleading toxicity reports to the federal government -allegations which call into question the integrity of key parts of the drug regulation process and cast doubt on the safety of some products.

The allegations are so serious that the Food and Drug Adminstration (FDA) has already investigated the testing procedures and test reports of a few companies, and it is about to launch an unprecedented inquiry into the work of dozens of others. On the basis of what it has turned up so far, FDA last week issued a bulky set of regulations which essentially instruct the drug industry how to conduct animal tests and warn that drugs could be pulled off the market if it is subsequently discovered that misleading reports on them have been filed with FDA. The objective of the proposed new regulations, an FDA official said last week, is "to make sure that drug companies compete with each other on the quality of their professional work rather than on their level of cost-cutting".

The concern over the quality of drug testing was triggered by a study published in the Journal of the National Cancer Institute by Mario Rustia and Philippe Shubik of the Eppley Research Institute. The study indicated that a commonly prescribed drug, known as Flagyl, increases the incidence of pulmonary and lymphoid tumours in mice. The paper raised eyebrows in FDA because the agency had in its files reports of two studies submitted by the drug's manufacturer, G. D. Searle and Co., which claimed to show that Flagyl is not carcinogenic in rats.

A thorough check of Searle's studv was then conducted bv Adrian Gross. an FDA scientist. Gross concluded that Searle's study did indeed show evidence of carcinogenicitv, but the companv's report didn't reflect all the data. FDA officials took the matter up with Searle, and two years later the company re-submitted its report. This time, Gross said in an interview last week, the summary agreed with the data, which would have been fine except that it was the data, not the summary, which had been altered. That finding prompted FDA to conduct a full-scale investigation into Searle's testing and reporting on several products. It was probably the most thorough federal investigation ever conducted of a drug company's scientific activities and it turned up some very disquieting findings.

The official report of the FDA investigation is among the most outspokenly critical federal documents that one could read. It states:

We have uncovered serious deficiencies in Searle's operations and practices which undermine the basis for reliance on Searle's integrity in conducting high quality animal research to accurately determine or characterise the toxic potential of its products ... Searle has not submitted all the facts of experiments to FDA, retaining unto itself the unpermitted option of filtering, interpreting, and not submitting information which we would consider material to the safety evaluation of the product. Some of our findings suggest an attitude of disregard for FDA's mission of protection of the public health by selectively reporting the results of studies in a manner which allavs the concerns of and questions of an FDA reviewer.

The task force which conducted the investigation recommended that the matter be turned over to the Justice Department, and that a grand jury be called to look into possible violation of the law. An FDA spokesman said last week that no grand jury investigation has yet been started, however. It should be noted that Searle's chief executive officer, Daniel Searle, acknowledged in Congressional testimony earlier this year that some "human errors" had occurred but he maintained that the FDA inquiry had found no evidence of fraud or misrepresentation by Searle personnel.

Whatever the outcome of the investigation, the Searle episode raises some very disturbing questions. FDA regulation of drugs and food additives is based largely on safety data submitted by the manufacturer of proposed new products. Thus, if manufacturers' test reports are unreliable, for any reason, much of the basis for FDA's regulatory actions could be oven to doubt. And animal tests, it should be noted, are particularlv important since they provide the chief means of identifying whether or not new products may have potential long- term problems, such as carcinogenicity, teratogenicity, and mutagenicityproblems which don't show up in clinical trials on humans.

Because of the serious implications if FDA is regulating drugs and food additives on the basis of unreliable data, Congress earlier this year added $\$ 16.4$ million to the agency's budget for an investigation to determine whether the problems uncovered at Searle are widespread in the industry. Senator Edward Kennedy, who was instrumental in securing the extra funds and in bringing the matter to public attention, noted last January that "if data are proven false and misleading, then the regulatory decisions may be tragically wrong".

FDA's investigation is about to get under way in earnest. During the next three months, inspectors from the agency will look into testing procedures and facilities of about 40 drug companies and independent testing laboratories. But FDA has already gathered alarming evidence that the problems are not limited to Searle.

Last week, the agency proposed a set of so-called Good Laboratory Practice (GLP) regulations which spell out standards which FDA will require for animal tests of drugs and food additives. In a preamble to the proposed regulations, FDA Commissioner Alexander M. Schmidt states that a number of recent investigations conducted by FDA in cases where the agency had reason to be suspicious of test reports "have identified significant problems in the manner in which nonclinical laboratory studies are being performed". The deficiencies, Schmidt said, were uncovered during inspections of "maior pharmaceutical firms, inspections of several private contract testing facilities. and internal reviews of toxicity studies of color additives conducted by FDA".

The problems included the following:

- "Pathology reports submitted to the agency were inconsistent with the original autopsy records".

- "Microscopic tissue slides were conducted by more than one pathologist, each of whom came to different conclusions, yet only the conclusions favourable to the drug were submitted to the agency".

- No records were kept for any individual animal in one long-term feeding study, "despite the fact that the records were required for proper analvsis of the study and were represented to the agency to exist".

- "Animals were recorded as normal for a variety of factors, including 
awareness, appearance, appetite, and thirst, when in fact the animals were dead".

- "Drugs were administered to animals in a manner which made it impossible to determine how much, if any, of the required dosage was actually ingested by the animal".

- In one toxicity study, "gross changes of tissue began to appear, yet management was not made aware of these alarming changes for approximately 4 to 8 months.

- In a study done by an independent testing laboratory. FDA was told that animal tissue samples had been examined when a review of laboratory records indicates that the tissue samples had never even been collected.

Such alarming, and possible fraudu- lent, incidents are supposed to be stopped, or at least made more difficult, by FDA's proposed GLP regulations. But the regulations would in fact not be unduly burdensome. They set standards for the training of laboratory personnel, the quality of facilities and equipment, the handling of test animals, and the keeping and reporting of test data. They also specify that a Quality Assurance Unit must be established in each facility to ensure that the GLP regulations are followed. In short, the proposed standards are no more strict than those which should already be in force in any selfrespecting facility.

Perhaps the most important aspect of the proposed regulations is that they spell out a number of sanctions which FDA could invoke if violations of the GLP standards are encountered. The ultimate sanction would be to remove a product from the market if FDA had approved it on the basis of test reports subsequently found to be false or misleading. Another proposed sanction would be to disqualify a test facility as a source of information in support of a future marketing permit. Such action would be tantamount to shutting down a contract laboratory which makes its living from conducting toxicity tests for the drug industry. Finally, FDA points out that deliberate faking or misleading reporting of test results could be subject to criminal prosecution.

The proposed GLP regulations are open for comment for 120 days and FDA plans to conduct public hearings on them early next year. By that time, the results of the inspection effort should be available to provide an indication of the scope of the problem.

\section{SEVESO}

\section{The problems deepen}

Italian authorities are now pondering how to clean up an area near Seveso in northern ltaly, following an accident last July which released large quantities of dioxin into the environment. Some important new information bearing on the problem has surfaced in the United States. Colin Norman reports

Dioxin in the soil of the most heavily contaminated area near Seveso can be expected to take up to 14 years to break down to levels at which the compound can no longer be detected. But there is unlikely to be much, if any, movement of dioxin in the soil, and the contamination will probably be confined to the upper 12 inches for a long time.

Those conclusions have emerged from an analysis of previously undisclosed studies conducted by the US Air Force, and from information gathered as a result of a bizarre dioxin contamination incident in Missouri in the early 1970s. The studies were ferreted out and analysed by Barry Commoner and Robert E. Scott, researchers at the Center for the Biology of Natural Systems at Washington University. Scott and Commoner have sent their conclusions to authorities investigating the Seveso disaster.

The Air Force studies, which were released to Commoner on October 28, involved soil tests with military herbicides contaminated with dioxin, left over from the Vietnam war. They involved heavy spraying of plots of land in Utah, Kansas and Florida, and subsequent monitoring of dioxin levels in the soil. Commoner and Scott conclude from the studies that the likely half-life for breakdown of dioxin in the soil at Seveso is ahout 250 days, a rate which suggests that it would take about 14 years for contamination to disappear from the most heavily affected area (Zone A) and about seven years to degrade to undetectable levels (about 10 parts per trillion) in the surrounding zone (Zone B).

But, in spite of an annual rainfall of about 60 inches in Florida, the Air Force study indicated that dioxin in the test plot there did not migrate in the soil. That finding is particularly important because there has been recent heavy rainfall in Seveso which has led to worries that the dioxin may have been washed through the soil into the groundwater. "It may be expected that the TCDD present in the upper layers of the soil at Seveso wil probably not migrate downward significantly, in spite of the heavy rainfall", Commoner and Scott conclude. Those obscrvations lead them to note that if the soil at Seveso is left in place, contamination is unlikely to spread, but alternatively if the upper layers of soil are stripped off and replaced with fresh soil, any dioxin left in the lower layers would not be expected to migrate to the surface.

The Air Force study has also yielded information on the effects of low levels of dioxin on wildlife. Samples of wildlife around the Florida test plot indicated significant bioaccumulation of the contaminant, and there was also a marked drop in the fertility of beech mice in the area. The observations lead
Commoner and Scott to conclude that wildlife at Seveso will be affected unless soil concentrations can be reduced to about 500 parts per trillion, compared with the average concentration of ahout 10 parts per million in Zone A. Such a reduction, they note, "could be most rapidly achieved by removing the upper layer of soil and replacing it with uncontaminated soil".

The other information analysed by Commoner and Scott was derived from observations following an incident in which waste oil heavily contaminated with dioxin was sprayed on the ground in four places in Missouri in May and June, 1971. The dioxin contamination was unknown at the time.

One application involved spraying the ground in a horse arena shortly before a show to keep down dust. Hundreds of birds and several horses died as a result of exposure to dioxin and three months later a young girl who had been playing in the arena was admitted to hospital with symptoms ranging from nosebleeds and headaches to severe disuria and hematuria. In October, four months after the spraying, between six and eight inches of topsoil was removed from the area and replaced with fresh soil, but deaths of horses, cats and other wildlife persisted. In April, 1974, four years after the accident, a further six inches of soil was removed, whereupon the toxic effects disappeared.

The original contamination in the arena was reckoned to be about 30 parts per million, a level similar to that in Zone $\mathbf{A}$, and thus the observations compiled by Commoner and Scott are directly relevant to the Seveso investigation.

Commoner and Scott conducted 